\title{
Aged mice show an increased mortality after anesthesia with a standard dose of ketamine/xylazine
}

\author{
Sandra Schuetze ${ }^{1,2^{*}}$ D, Anja Manig ${ }^{1,3}$, Sandra Ribes ${ }^{1}$ and Roland Nau ${ }^{1,4}$
}

\begin{abstract}
Geriatric animal models are crucial for a better understanding and an improved therapy of age-related diseases. We observed a high mortality of aged mice after anesthesia with a standard dose of ketamine/xylazine, an anesthetic regimen frequently used in laboratory veterinary medicine. C57BL/6-N mice at the age of $2.14 \pm 0.23$ months (young mice) and $26.31 \pm 2.15$ months (aged mice) were anesthetized by intraperitoneal injection of $2 \mathrm{mg}$ ketamine and $0.2 \mathrm{mg}$ xylazine. 4 of 26 aged mice (15.4\%) but none of 26 young mice died within 15 min after injection of the anesthetics. The weight of aged mice was significantly higher than that of young mice $(32.8 \pm 5.4 \mathrm{~g}$ versus $23.2 \pm 3.4 \mathrm{~g}, p<0.0001)$. Thus, aged mice received lower doses of anesthetics in relation to their body weight which are within the lower range of doses recommended in the literature or even beneath. There were no differences between deceased and surviving aged mice concerning their sex, weight and their motor performance prior to anesthesia.

Our data clearly show an age-related increase of mortality upon anesthesia with low standard doses of ketamine/ xylazine. Assessment of weight and motor performance did not help to predict vulnerability of aged mice to the anesthetics. Caution is necessary when this common anesthetic regimen is applied in aged mice: lower doses or the use of alternative anesthetics should be considered to avoid unexpected mortality.

The present data from our geriatric mouse model strongly corroborate an age-adjusted reduction of anesthetic doses to reduce anesthesia-related mortality in aged individuals.
\end{abstract}

Keywords: Aging, Anesthetics, Geriatric mouse model, Mortality, C57BL/6

\section{Introduction}

The increased life expectancy is going hand in hand with an increase of age-related diseases, such as neurodegenerative diseases, cancer, and atherosclerosis [1]. Aged persons are more vulnerable to infections and other external stressors [2, 3]. Because of the age-related decline of organ functions and age-related changes of pharmacokinetic and pharmacodynamic features, elderly individuals react differently to therapeutics and anesthetics $[4,5]$. To improve therapies for the growing group of geriatric persons, age-related diseases and conditions require proper scientific investigation. In clinical

\footnotetext{
* Correspondence: sandra.schuetze@medizin.uni-goettingen.de

'Institute of Neuropathology, University Medical Center Göttingen,

Robert-Koch-Str. 40, D-37075 Göttingen, Germany

2Department of Geriatrics, AGAPLESION Frankfurter Diakonie Kliniken, 60431

Frankfurt am Main, Germany

Full list of author information is available at the end of the article
}

studies, nowadays there is a trend to pay more attention to persons at an age over 80 years, which have been excluded from many studies in the past $[6,7]$. Geriatric animal models are needed for a better understanding of age-related changes and processes. Recently, geriatric mouse models for frailty and sarcopenia including C57BL/6 mice up to an age of 28 months have been established [8-10]. Thus, aged mice become increasingly important for basic research. This is reflected by the fact that animal breeding companies started to offer aged mice up to an age of more than 24 months. Many interventions during mouse experiments require anesthesia, and the ketamine/xylazine regimen is widely used [11-14]. There are some studies which primarily focus on the effects of these anesthetics on the mouse creature [15-18], the influence of mouse strain and sex on the susceptibility to anesthetics [19], or the optimization

(c) The Author(s). 2019 Open Access This article is distributed under the terms of the Creative Commons Attribution 4.0 International License (http://creativecommons.org/licenses/by/4.0/), which permits unrestricted use, distribution, and 
of anesthesia protocols in mice [20-22]. Although advanced age over 18 months has been considered to influence susceptibility of mice to anesthetics [13], to our knowledge, experimental studies or recommendations primarily addressing anesthetic regimes for geriatric mice do not exist so far. ARRIVE guidelines specify to pay attention to anesthesia [23]. However, the crucial role of anesthetics is often ignored or underestimated in the experimental design and later publication of animal research models $[24,25]$.

We established a geriatric mouse model for Escherichia coli (E. coli) meningitis [26], in which young and aged mice received intraperitoneal anesthesia with standard doses of ketamine/xylazine before intracerebral injection of $E$. coli $\mathrm{K} 1$. During these experiments, we observed a substantial mortality of aged mice under this standard anesthetic regimen frequently used in laboratory veterinary medicine. We consider this observation highly relevant for our further work with geriatric mouse models and for other researchers performing experiments with aged mice.

\section{Methods/ experimental \\ Animals}

Animal experiments were approved by the Animal Care Committee of the University Medical Center Göttingen, Germany, and by the Niedersächsisches Landesamt für Verbraucherschutz und Lebensmittelsicherheit (LAVES), Braunschweig, Lower Saxony, Germany.

C57BL/6-N mice were bred in the animal care facility (Zentrale Tierexperimentelle Einrichtung) of the of the University Medical Center Göttingen, Germany, and housed under a $12: 12 \mathrm{~h}$ light:dark cyle, $20^{\circ} \mathrm{C}$ room temperature and $55 \%$ humidity in compatible groups of maximum 5 animals until they reached the intended age. They were provided with free choice standard rodent diet and bottled tap water. 26 C57BL/6-N mice at the age of $2.14 \pm 0.23$ months (young mice) and 26 C57BL/6-N mice at the age of $26.31 \pm 2.15$ months (aged mice) received anesthesia. Prior to anesthesia, all mice were weighed and their motor performance was assessed using the tight rope test.

\section{Tight rope test}

Mice were placed with their front paws in the middle of a $60 \mathrm{~cm}$ long rope tightly spanned about $60 \mathrm{~cm}$ above a padded floor. The time until one end of the rope was reached was measured, and a performance score was assigned (minimum score 0 , maximum score 20). Mice reaching one end in $\leq 6 \mathrm{~s}$ were given score 0 . An additional point was added for every 6 additional seconds needed. Mice hanging for $60 \mathrm{~s}$ on the rope but not reaching one end were given a score of 10 . Mice which fell down before that time received additional points to the 10 points for every $6 \mathrm{~s}$ falling earlier than $60 \mathrm{~s}$ [27].

\section{Anesthetic dilution and administration}

Ketamine $10 \% \quad(100 \mathrm{mg} / \mathrm{ml}$; Medistar, Ascheberg, Germany) and xylazine $2 \%(20 \mathrm{mg} / \mathrm{ml}$; Riemser, Greifswald, Germany) were combined in a single insulin syringe ( 2 parts of ketamine and 1 part of xylazine). Mice were manually restrained, and $30 \mu \mathrm{l}$ of the anesthetic mixture were injected intraperitoneally into the right lower quadrant of the abdomen using a 25 -gauge needle. Independently of the body weight, each mouse received $2 \mathrm{mg}$ ketamine and $0.2 \mathrm{mg}$ xylazine.

\section{Statistics}

GraphPad Prism 5.0 Software (GraphPad Software, San Diego, California, USA) was used to perform statistical analyses and graphical presentation. Log-rank test was performed for the comparison of survival curves. Weights of mice and doses of anesthetics are expressed as means \pm standard deviations (SD) and were compared using the Student's $t$-test. The tight rope test scores are expressed as medians (25th percentile/75th percentile). Mann-Whitney $U$-test was performed to compare the tight rope test scores between the groups. Sex distributions were compared using the Chi-squared test. $P$-values $<0.05$ were considered statistically significant.

\section{Results}

4 of 26 aged mice (15.4\%) died within 15 min after injection of ketamine/xylazine $(2 \mathrm{mg} / 0.2 \mathrm{mg})$, whereas none of the 26 young mice died from the anesthesia $(p=$ 0.039; Fig. 1).

Sex distribution was similar in both groups [young mice: 17 of 26 mice female (65\%), aged mice: 18 of 26 mice female (69\%); Table 1]. Weight of aged mice $(32.8 \pm 5.4 \mathrm{~g})$ was substantially higher than that of young mice $(23.2 \pm 3.4 \mathrm{~g} ; p<0.0001$; Fig. $2 \mathrm{a}$, Table 1$)$. Young mice showed a better motor performance than aged mice as assessed by the tight rope test, with lower scores indicating a better performance: tight rope test scores [medians (25th percentile/75th percentile)] of young mice were significantly lower than those of aged mice $[1(1 / 2)$ versus $16(9.75 / 18.25) ; p<0.0001$; Fig. 2b]. There was no significant difference between surviving and deceased aged mice concerning their body weight $(33.3 \pm 5.0 \mathrm{~g}$ versus $30.2 \pm 7.5 \mathrm{~g} ; p=0.30$; Fig. 2a, Table 1). and their tight rope test scores [16(10/18.25) versus 11(2.5/19.5); $p=0.83$; Fig. $2 b]$.

Ages of surviving and deceased aged mice did not differ significantly ( $p=0.49$; Table 1$)$, and sex distribution of surviving and deceased aged mice was similar $(p=0.79$; Table 1$)$. 


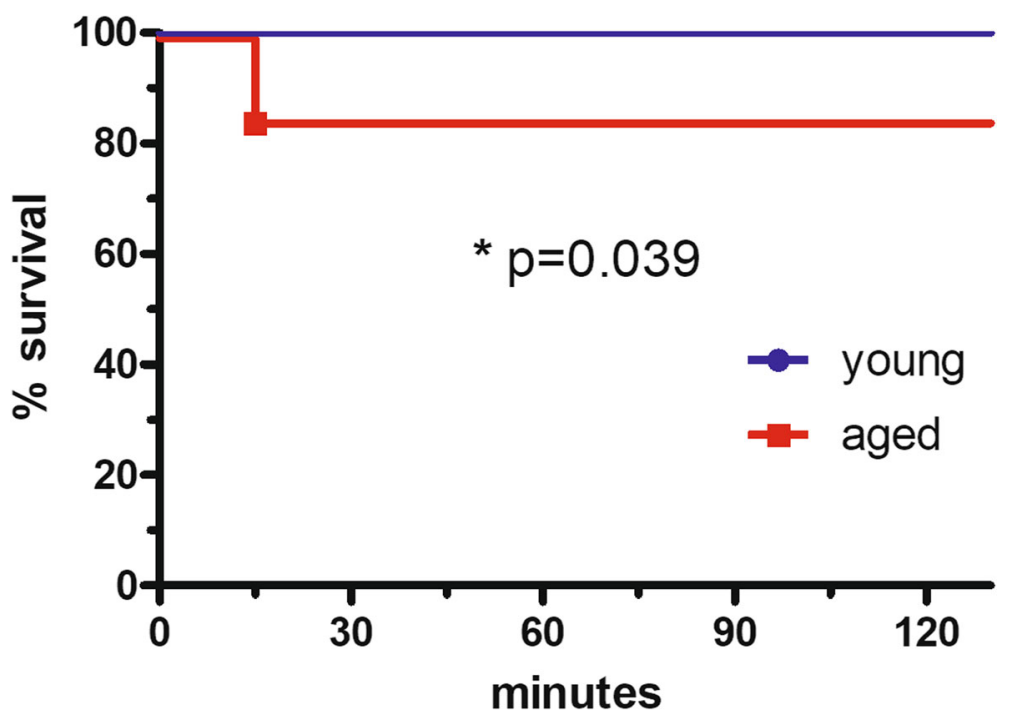

Fig. 1 Mortality of young and aged mice after anesthesia with ketamine/xylazine. Kaplan-Meier curves of young mice (2 months) and aged mice (26 months) after intraperitoneal injection of $2 \mathrm{mg}$ ketamine and $0.2 \mathrm{mg}$ xylazine. 15.4\% of the aged mice but none of the young mice died after anesthesia (log-rank test: $p=0.039)$

In relation to their body weight, aged mice received approximately $70 \%$ of the doses of ketamine and xylazine administered to young mice (aged mice: $62.6 \pm 10.3$ $\mathrm{mg} / \mathrm{kg}$ ketamine, $6.3 \pm 1.0 \mathrm{mg} / \mathrm{kg}$ xylazine; young mice: $87.9 \pm 12.0 \mathrm{mg} / \mathrm{kg}$ ketamine, $8.8 \pm 1.2 \mathrm{mg} / \mathrm{kg}$ xylazine; $p<$ 0.0001; Table 1). Doses of the anesthetics did not differ significantly between surviving aged mice $(61.4 \pm 9.0 \mathrm{mg} /$ $\mathrm{kg}$ ketamine, $6.2 \pm 0.9 \mathrm{mg} / \mathrm{kg}$ xylazine) and deceased aged mice $(69.3 \pm 16.0 \mathrm{mg} / \mathrm{kg}$ ketamine, $6.9 \pm 1.6 \mathrm{mg} / \mathrm{kg}$ xylazine; $p=0.17$; Table 1 ).

\section{Discussion}

Our data clearly show that a standard dose of ketamine/ xylazine with no related severe adverse effects in young mice can be detrimental in aged animals. We observed a mortality of $15 \%$ in mice with an age of approximately 2 years, although aged mice received substantially lower doses of the anesthetics per body weight. Weight and motor performance assessed before anesthesia were not able to predict outcome.

The combination of ketamine and xylazine is one of the most frequently used anesthetic regimens in rodents
[11-14]. Hypotension and heart rate decrease are the major adverse reactions of ketamine/xylazine in mice, whereas respiratory functions are less affected [14]. Widely used doses of ketamine $100 \mathrm{mg} / \mathrm{kg}$ and xylazine $10 \mathrm{mg} / \mathrm{kg}$ have been shown to result in a sufficient anesthetic depth and low respiratory depression [14]. These doses have also been used for anesthesia in our mouse meningitis models since many years without causing problems concerning mortality [27, 28]. Reported doses for ketamine/xylazine in mice range from 60 to $200 \mathrm{mg} / \mathrm{kg}$ ketamine and $4-20 \mathrm{mg} / \mathrm{kg}$ xylazine $[11,12]$. In the present study, we induced anesthesia by injection of $2 \mathrm{mg}$ ketamine and $0.2 \mathrm{mg}$ xylazine per mouse independently of the body weight. Thus, the mouse with the lowest weight $(19 \mathrm{~g})$ received approximately $100 / 10 \mathrm{mg} / \mathrm{kg}$ ketamine/xylazine; all other mice received lower doses. The mouse with the highest weight (44 g) received only $45 / 4.5 \mathrm{mg} / \mathrm{kg}$ ketamine/xylazine. According to their higher body weight, aged mice received significantly lower doses than young mice (only approximately $70 \%$ of the doses of young mice) which are within the lower range of reported doses or even beneath

Table 1 Comparison of age, sex distribution, and doses of anesthetics between young and aged mice (left column) and between surviving and deceased aged mice (right column)

\begin{tabular}{|c|c|c|c|c|c|c|}
\hline & young $(n=26)$ & aged $(n=26)$ & $p$ & surviving aged $(n=22)$ & deceased aged $(n=4)$ & $p$ \\
\hline age in months (mean $\pm S D$ ) & $2.14 \pm 0.23$ & $26.31 \pm 2.15$ & $<0.0001$ & $26.18 \pm 2.26$ & $27.0 \pm 1.35$ & 0.49 \\
\hline sex distribution [female: $\mathrm{n}(\%)]$ & $17(65 \%)$ & $18(69 \%)$ & 0.77 & $15(68 \%)$ & $3(75 \%)$ & 0.79 \\
\hline weight in $\mathrm{g}($ mean $\pm \mathrm{SD})$ & $23.2 \pm 3.4$ & $32.8 \pm 5.4$ & $<0.0001$ & $33.3 \pm 5.0$ & $30.2 \pm 7.5$ & 0.30 \\
\hline ketamine dose (mg/kg) & $87.9 \pm 12.0$ & $62.6 \pm 10.3$ & $<0.0001$ & $61.4 \pm 9.0$ & $69.3 \pm 16.0$ & 0.17 \\
\hline xylazine dose (mg/kg) & $8.8 \pm 1.2$ & $6.3 \pm 1.0$ & $<0.0001$ & $6.2 \pm 0.9$ & $6.9 \pm 1.6$ & 0.17 \\
\hline
\end{tabular}




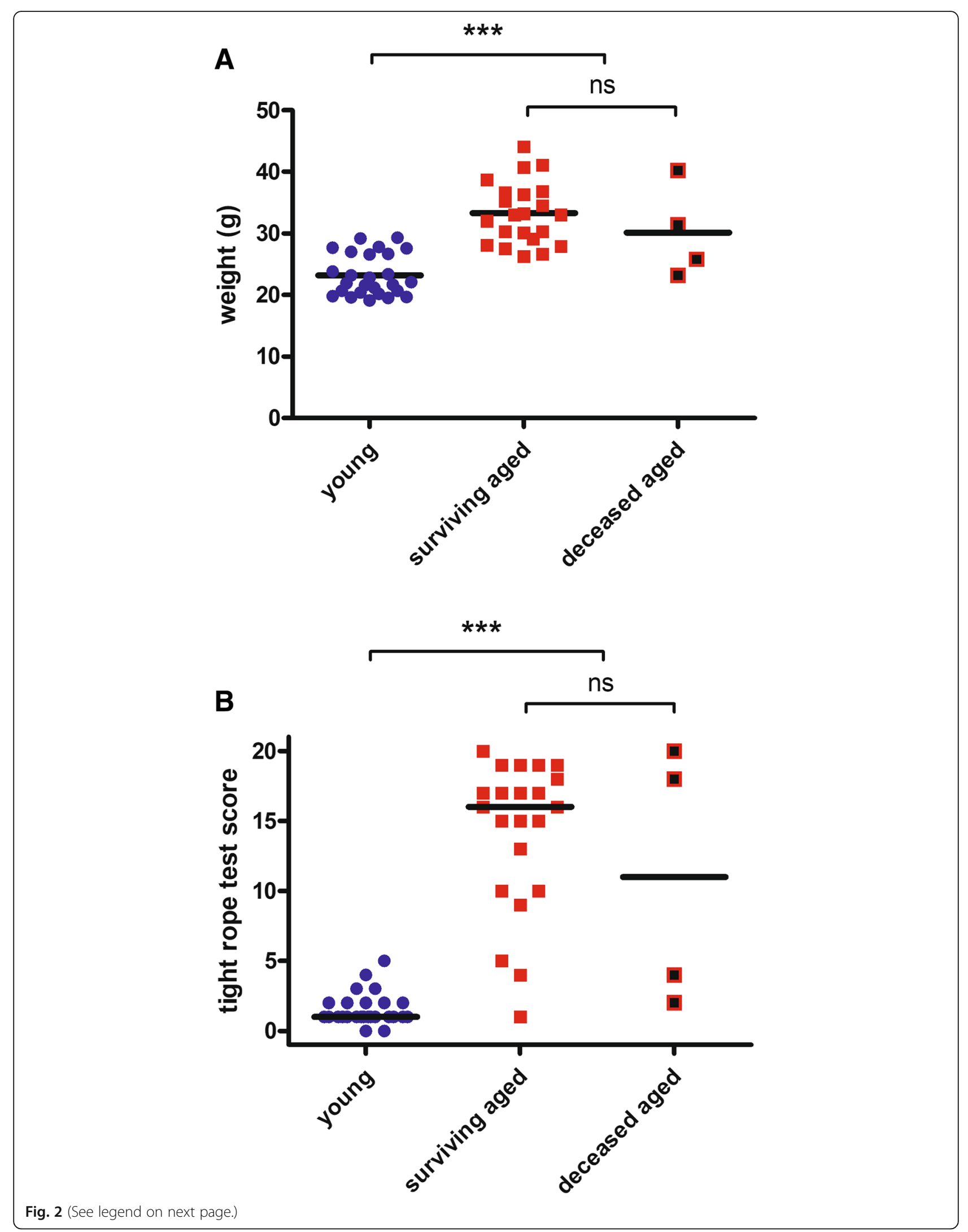


(See figure on previous page.)

Fig. 2 Weight and motor performance. a: Weight of aged mice was significantly higher than that of young mice ( $32.8 \pm 5.4 \mathrm{~g}$ versus $23.2 \pm 3.4 \mathrm{~g}$; $p<0.0001$ ). Weight of surviving and deceased aged mice did not differ ( $33.3 \pm 5.0 \mathrm{~g}$ versus $30.2 \pm 7.5 \mathrm{~g} ; p=0.30$ ). Data are presented as individual values and means and were compared using Student's $t$-test ${ }^{* * *} p<0.0001 ; \mathrm{ns}=$ not significant). $\mathbf{b}$ : Tight rope test scores [medians (25th percentile/75th percentile)] of aged mice were significantly higher than those of young mice [16(9.75/18.25) versus $1(1 / 2) ; p<0.0001]$. Tight rope test scores of surviving and deceased aged mice did not differ [16(10/18.25) versus 11(2.5/19.5); $p=0.83$ ]. Data are presented as individual values and medians and were compared using the Mann-Whitney U-test $\left({ }^{* *} p<0.0001\right.$; ns = not significant)

$[11,12]$. Although administered doses of anesthetics were not significantly different between surviving and deceased aged mice, in tendency, deceased mice received higher doses $(69.3 \pm 16.0 / 6.9 \pm 1.6 \mathrm{mg} / \mathrm{kg}$ versus $61.4 \pm 9.0 / 6.2 \pm$ $0.9 \mathrm{mg} / \mathrm{kg}$ ). All surviving mice developed sufficient depth of anesthesia to perform a painless intracerebral injection and recovered from anesthesia without apparent deficits. Injection of weight-adjusted amounts of ketamine and xylazine aiming at equal doses in young and aged animals (e.g. $100 / 10 \mathrm{mg} / \mathrm{kg}$ ) might have resulted in a much higher mortality within the group of aged mice.

The avoidance of non-intended death of laboratory animals has highest priority for all researchers performing animal experiments. Therefore, an unintended mortality of $15 \%$ upon anesthesia in aged mice is not acceptable and must urgently be avoided in future experiments. It is not clear from our experiments, which parameters caused the increased vulnerability of aged mice to the anesthetics used. Easily to perform assessment of weight and motor function did not help to predict vulnerability of mice to ketamine and xylazine.

The NMDA antagonist ketamine leads to an increased heart rate and hypertension, the alpha-two adrenoceptor agonist xylazine has biphasic cardiovascular effects with bradycardia and hypertension within the first $15 \mathrm{~min}$ followed by hypotension and reduced cardiac excitability as well as arrhythmias [5]. The finding that death occurred within $15 \mathrm{~min}$ after injection of anesthetics allows excluding hypotension as cause of decease. Reduction of respiratory frequency and blood oxygen saturation was similar in young and aged rats after injection of ketamine/xylazine $80 / 10 \mathrm{mg} / \mathrm{kg}$, whereas cardiac frequency was significantly more reduced in aged compared to young rats already shortly after injection of the anesthetics [29]. This suggests that most probably the early cardiac effects of the alpha-two agonist xylazine resulting in a more pronounced bradycardia in aged individuals led to death in aged mice.

Caution is necessary when this common anesthetic regimen is applied in aged mice. Weight-adjustment of anesthetics which is recommended in many anesthetic protocols should be avoided in geriatric mouse models as it most probably results in overdosing and dramatically unexpected high mortality of aged mice. However, age-corrected reduction of anesthetic doses seems to be essential to save the life of valuable aged mice. Our results suggest that only doses of ketamine/xylazine below $60 / 6 \mathrm{mg} / \mathrm{kg}$ should be used for anesthesia of aged mice. Furthermore, alternative anesthetic regimens should be evaluated in geriatric mice, e.g. regimens avoiding or reducing alpha-two agonists, such as xylazine, in order to minimize the unintended reduction of cardiac frequency which has been shown to be more pronounced in aged individuals [5, 29]. Isoflurane is recommended in many protocols, including anesthesia for brain interventions, as it allows a tight control of the anesthesia plane and a fast recovery after surgery [30]. However, isoflurane affects the expression of key neuroimmunomodulators in the hippocampus of aged mice and might contribute to the development of postanesthesia cognitive impairment; furthermore, it leads to an impaired systemic immune response, e.g. by inhibition of macrophage functions and bacterial clearance [31]. Thus, isoflurane cannot be recommended for anesthesia in aged individuals, and particularly not for experiments addressing immunologic questions. The use of much lower doses of ketamine/xylazine (e.g. 10/1 mg/ $\mathrm{kg}$ ) followed by subcutaneous injection of the analgesic buprenorphine [32] and if necessary re-injection with ketamine alone [30] could be an alternative anesthetic regimen in order to avoid the potentially detrimental cardiovascular effects of xylazine.

Elderly patients are undergoing surgical procedures with increasing frequency $[33,34]$. They are at a relatively higher risk of perioperative mortality and morbidity compared to younger patients $[4,35]$. To what extent anesthesia is causative for this, is difficult to study in humans. Guidelines recommend a $25-50 \%$ reduction of anesthetics in elderly patients [34]. However, suggested age-correction of anesthetic doses often is not sufficiently performed in clinical practice, and this failure might contribute to increased perioperative morbidity and mortality [36, 37].

\section{Conclusions}

The present data from our geriatric mouse model strongly corroborate the necessity of reduction of anesthetic doses and adaption of anesthetic regimens in aged individuals. Animal experiments specifically designed to compare effects of anesthetics in aged and young animals might help to identify parameters accounting for the increased susceptibility to anesthesia and to reduce the anesthesia-related perioperative mortality of aged individuals. 


\section{Abbreviations}

E. coli: Escherichia coli; SD: Standard deviation

\section{Acknowledgements}

Not applicable.

\section{Authors' contributions}

SS and AM performed the experiments. SS, SR, and RN analyzed and discussed the results. SS wrote the manuscript. All authors read and approved the final version of the manuscript.

\section{Funding}

The study was supported by a grant of the Robert Bosch Stiftung, Stuttgart Forschungskolleg Geriatrie (to SS).

\section{Availability of data and materials}

The datasets used and/or analyzed during the current study are available from the corresponding author on reasonable request.

\section{Ethics approval and consent to participate}

Not applicable.

\section{Consent for publication}

Not applicable.

\section{Competing interests}

The authors declare that they have no competing interests.

\section{Author details}

'Institute of Neuropathology, University Medical Center Göttingen, Robert-Koch-Str. 40, D-37075 Göttingen, Germany. ${ }^{2}$ Department of Geriatrics, AGAPLESION Frankfurter Diakonie Kliniken, 60431 Frankfurt am Main, Germany. ${ }^{3}$ Department of Clinical Neurophysiology, University Medical Center Göttingen, 37075 Göttingen, Germany. ${ }^{4}$ Department of Geriatrics, Evangelisches Krankenhaus Göttingen-Weende, 37075 Göttingen, Germany.

\section{Received: 1 May 2019 Accepted: 4 July 2019}

\section{Published online: 24 July 2019}

\section{References}

1. United Nations. World population prospects: the 2015 revision. New York; 2015. https://www.un.org/en/development/desa/publications/worldpopulation-prospects-2015-revision.html.

2. Gavazzi G, Krause GH. Ageing and infection. Lancet Infect Dis. 2002;2: 659-66.

3. Cesari M, Nobili A, Vitale G. Frailty and sarcopenia: from theory to clinical implementation and public health relevance. Eur J Intern Med. 2016;35:1-9.

4. Griffiths R, Beech F, Brown A, Dhesi J, Foo I, Goodall J, Harrop-Griffiths W, Jameson J, Love N, Pappenheim K, White S (Association of Anaesthetists of Great Britain and Ireland). Guidelines - Peri-operative care of the elderly 2014. Anesthesia 2014; 69:81-98.

5. Hughes JML. Anaesthesia for the geriatric dog and cat. Ir Vet J. 2008;61:380-7.

6. Van Spall HG, Toren A, Kiss A, Fowler RA. Eligibility criteria of randomized controlled trials published in high-impact general medical journals: a systematic sampling review. JAMA. 2007;297:1233-40.

7. Van Deudekom FJ, Postmus I, van der Ham DJ, Polthof AB, Broekhuizen $K$, Blauw GJ, Mooijaart SP. External validity of randomized controlled trials in older adults, a systematic review. PLoS One. 2017;12:3.

8. Gomez-Cabrera MC, Garcia-Valles R, Rodriquez-Manas L, Garcia-Garcia FJ, Olaso-Gonzalez G, Salvador-Pascual A, Tarazona-Santabalbina FJ, Vina JJ. A new frailty score for experimental animals based on the clinical phenotype: inactivity as a model of frailty. J Gerontol A Biol Sci Med Sci. 2017;72:885-91.

9. Kane AE, Huizer-Pajkos A, Mach J, Mitchell SJ, de Cabo R, Le Couteur DG, Howlett SE, Hilmer SN. A comparison of two mouse frailty assessment tools. J Gerontol A Biol Sci Med Sci. 2017;72:904-9.

10. Van Dijk M, Nagel J, Dijk FJ, Salles J, Verlaan S, Walrand S, van Norren K, Luiking Y. Sarcopenia in older mice is characterized by a decreased anabolic response to a protein meal. Arch Gerontol Geriatr. 2017:69:134-43.

11. Arras M, Autenried P, Rettich A, Spaeni D, Rülicke T. Optimization of intraperitoneal injection anesthesia in mics: drugs, dosages, adverse effects, and anesthesia depth. Comp Med. 2001;51:443-56.
12. Buitrago S, Martin TE, Tetens-Woodring J, Belicha-Villanueva A, Wilding GE. Safety and efficacy of various combinations of injectible anesthetics in BALB/C mice. J Am Assoc Lab Anim Soc. 2008;47:11-7.

13. Gargiulo S, Greco A, Gramanzini M, Esposito S, Affuso A, Brunetti A, Vesce G. Mice anesthesia, analgesia, and care, part I: anesthetic considerations in preclinical research. ILAR J. 2012;53:E55-69.

14. Tsukamoto A, Serizawa K, Sato R, Yamazaki J, Inomata T. Vital signs monitoring during injectable and inhalant anesthesia in mice. Exp Anim. 2015;64:57-64.

15. Chery R, Gurden H, Martin C. Anesthetic regimes modulate the temporal dynamics of local field potential in the mouse olfactory bulb. J Neurophysiol. 2014;111:908-17.

16. Huang L, Yang G. Repeated exposure to ketamine-xylazine during early development impairs motor learning-dependent dendritic spine plasticity in adulthood. Anesthesiology. 2015;122:821-31.

17. Koehn D, Meyer KJ, Syed NA, Anderson MG. Ketamine/Xylazine-induced corneal damage in mice. PLoS One. 2015;10:7.

18. Dholakia U, Clark-Price SC, Keating SCJ, Stern AW. Anesthetic effects and body weight changes associated with ketamine-xylazine-lidocaine administered to CD-1 mice. PLoS One. 2017;12:9.

19. Lovell DP. Variation in pentobarbitone sleeping time in mice. 1. Strain and sex differences. Lab Anim. 1986;20:85-90.

20. Erickson RL, Terzi MC, Jaber SM, Hankenson FC, McKinstry-Wu A. Intraperitoneal continous-rate infusion for the maintenance of anesthesia in laboratory mice (mus musculus). J Am Assoc Lab Anim Soc. 2016;55:548-57.

21. Levin-Arama M, Abraham L, Waner T, Harmelin A, Steinberg DM, Lahav T, Harlev M. Subcutaneous compared with intraperitoneal ketamine-xylazine for anaethesia of mice. J Am Assoc Lab Anim Soc. 2016;55:794-800.

22. Janssen CF, Maiello P, Wright MJ Jr, Kracinovsky KB, Newsome JT. Comparison of atipamezole with yohimbine for antagonism of xylazine in mice anesthetized with ketamine and xylazine. J Am Assoc Lab Anim Soc. 2017:56:142-7.

23. Kilkenny C, Browne WJ, Cuthill IC, Emerson M, Altman DG. Improving Bioscience Research Reporting: The ARRIVE Guidelines for Reporting Animal Research. PLoS Biol. 2010;8:6.

24. Zuurbier CJ, Koeman A, Houten SM, Hollmann MW, Florijn WJ. Optimizing anesthetic regimen for surgery in mice through minimization of hemodynamic, metabolic, and inflammatory perturbations. Exp Biol Med. 2014;239:737-46.

25. Carbone L, Austin J. Pain and laboratory animals: publication practices for better data reproducibility and better animal welfare. PLoS One. 2016;11:5.

26. Schütze S, Ribes S, Kaufmann A, Manig A, Scheffel J, Redlich S, Bunkowski S, Hanisch UK, Brück W, Nau R. Higher mortality and impaired elimination of bacteria in aged mice after intracerebral infection with E. coli are associated with an age-related decline of microglia and macrophage functions. Oncotarget. 2014;5:12573-92.

27. Wellmer A, Noeske C, Gerber J, Munzel U, Nau R. Spatial memory and learning deficits after experimental pneumococcal meningitis in mice. Neurosci Lett. 2000:296:137-40.

28. Redlich S, Ribes S, Schütze S, Nau R. Palmitoylethanolamide stimulates phagocytosis of Escherichia coli K1 by macrophages and increases the resistance of mice against infections. J Neuroinflamm. 2014;11:108.

29. Giroux MC, Santamaria R, Helie P, Burns P, Beaudry F, Vachon P. Physiological, pharmacokinetic and liver metabolism comparisons between 3-, 6-, 12 and 18-month-old male Sprague Dawley rats under ketaminexylazine anesthesia. Exp Anim. 2016;65:63-75.

30. Bielefeld P, Sierra A, Encinas JM, Maletic-Savatic M, Anderson A, Fitzsimons CP. A standardized protocol for stereotaxic intrahippocampal administration of kainic acid combined with electroencephalographic seizure monitoring in mice. Front Neurosci. 2017;11:160.

31. Friese MB, Nathan M, Culley DJ, Crosby G. Isoflurane anesthesia impairs the expression of immune neuromodulators in the hippocampus of aged mice. PLoS One. 2018;13(12):e0209283.

32. Davis MP. Twelve reasons for considering buprenorphine as a frontline analgesic in the management of pain. J Support Oncol. 2012;10:209-19.

33. Etzioni DA, Liu JH, Maggard MA, Ko CY. The aging population and its impact on the surgery workforce. Ann Surg. 2003;238:170-7.

34. Mohanty S, Rosenthal RA, Russell MM, Neumann MD, Ko CY, Esnaola NF. Optimal perioperative management of the geriatric patient: a best practices guideline from the American College of Surgeons NSQIP and the American Geriatrics Society. J Am Coll Surg. 2016;222:930-47. 
35. Hamel MB, Henderson WG, Khuri SF, Daley J. Surgical outcomes for patients aged 80 and older: morbidity and mortality from major noncardiac surgery. J Am Geriatr Soc. 2005;53:424-9.

36. Akhtar S, Liu J, Heng J, Dai F, Schonberger RB, Burg MM. Does intravenous induction dosing among patients undergoing gastrointestinal surgical procedures follow current recommendations: a study of contemporary practice. J Clin Anesth. 2016;33:208-15.

37. Akhtar S, Heng J, Dai F, Schonberger RB, Burg MM. A retrospective observational study of anesthetic induction dosing practices in female elderly surgical patient: are we overdosing older patients? Drugs Aging. 2016:33:737-46.

\section{Publisher's Note}

Springer Nature remains neutral with regard to jurisdictional claims in published maps and institutional affiliations.

Ready to submit your research? Choose BMC and benefit from:

- fast, convenient online submission

- thorough peer review by experienced researchers in your field

- rapid publication on acceptance

- support for research data, including large and complex data types

- gold Open Access which fosters wider collaboration and increased citations

- maximum visibility for your research: over $100 \mathrm{M}$ website views per year

At BMC, research is always in progress.

Learn more biomedcentral.com/submissions 